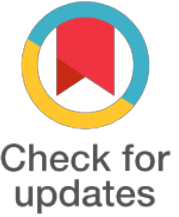

*For correspondence:

pvphuc@hcmus.edu.vn

Competing interests: The authors declare that no competing interests exist.

Received: 2017-08-06

Accepted: 2017-08-18

Published: 2017-09-05

Copyright The Author(s) 2017. This article is published with open access by BioMedPress (BMP).

This article is distributed under the terms of the Creative Commons Attribution License (CC-BY 4.0) which permits any use, distribution, and reproduction in any medium, provided the original author(s) and the source are credited.

\section{Autologous and allogeneic transplantation of adipose derived stem cells have similar effects for type 1 diabetes mellitus treatment in mouse models}

\author{
Anh Bui Nguyen Tu, Oanh Thi-Kieu Nguyen, Cong Le-Thanh Nguyen, Loan \\ Thi-Tung Dang, Phuc Van Pham, Ngoc Kim Phan
}

Laboratory of Stem Cell Research and Application, University of Science, Vietnam National

University, Ho Chi Minh City

\section{Abstract}

Background: Type 1 diabetes mellitus ( $\left.T_{1} D\right)$ disease is caused by lesions or dysfunction of beta cells of pancreatic islets, causing less insulin to be secreted into the blood and thereby increasing glucose levels in the blood. In this study, we evaluated and compared the efficiency of treatment for $\mathrm{T}_{1} \mathrm{D}$ using autograft and allograft adipose-derived stem cells (ADSCs).

Methods: ADSCs were collected from the belly of mice before they were injected using a single dose of streptozotocin ( $100 \mathrm{mg} / \mathrm{kg}$ ) to induce T1D. T1D mice were intravenously injected with a dose of 2x106 ADSCs into the tail vein. Therapeutic efficacy was assessed by survival rate, blood glucose levels, serum insulin levels, histology and immunohistochemistry of pancreatic islets.

Results: The results showed that both autograft and allograft transplantation of ADSCs demonstrated similarities in mortality rate, blood glucose level, blood insulin level, quantity and size of pancreatic islets. Both transplantations significantly improved T1D mice, which showed a decrease in mortality rate as well as blood glucose level, and increases in blood insulin level, quantity and size of pancreatic islets.

Conclusion: The similar results suggest that both autologous and allogeneic transplantations of ADSCs are promising therapy for T1D treatment.

\section{Keywords}

Type 1 diabetes mellitus, adipose-derived stem cells, allograft, autograft, mice

Funding

References 